\title{
Determination Of Corrosion Inhibitor Criteria For Type III/IIIA Tanks During Salt Dissolution Operations - Interim Report
}

\author{
K. M. Counts \\ B. J. Wiersma \\ J. I. Mickalonis
}

\author{
Savannah River National Laboratory \\ Materials Science and Technology Directorate
}

Publication Date: December 2007

\section{Washington Savannah River Company Savannah River Site Aiken SC 29808}

This document was prepared in connection with work done under Contract No. DE-AC0996SR18500 with the U. S. Department of Energy 


\section{DISCLAIMER}

This report was prepared as an account of work sponsored by an agency of the United States Government. Neither the United States Government nor any agency thereof, nor any of their employees, makes any warranty, express or implied, or assumes any legal liability or responsibility for the accuracy, completeness, or usefulness of any information, apparatus, product, or process disclosed, or represents that its use would not infringe privately owned rights. Reference herein to any specific commercial product, process, or service by trade name, trademark, manufacturer, or otherwise does not necessarily constitute or imply its endorsement, recommendation, or favoring by the United States Government or any agency thereof. The views and opinions of authors expressed herein do not necessarily state or reflect those of the United States Government or any agency thereof. 
WSRC-STI-2007-00552

October 2007

Revision 0

DOCUMENT: WSRC-STI-2007-00552

TITLE: Determination Of Corrosion Inhibitor Criteria For Type III/IIIA Tanks During Salt Dissolution Operations - Interim Report

\section{APPROVALS:}

Date:

K. M. Counts, Author

Materials Performance and Corrosion Tech. Materials Technology Section

Date:

J. I. Mickalonis, Author

Materials Performance and Corrosion Tech . Materials Technology Section

Date:

B. J. Wiersma, Author

Materials Performance and Corrosion Tech . Materials Technology Section
Date:

C. M. Cole, Liquid Waste Technical Reviewer Tank Farm Process Engineering Liquid Waste

Date:

K. S. Parkinson, Liquid Waste Lead

Tank Farm Process Engineering

Liquid Waste

Date:

D. J. Martin, Manager

Tank Farm Process Engineering

Liquid Waste

Date:

K. H. Subramanian, Technical Reviewer

Materials Performance and Corrosion Technology

Materials Technology Section

Date:

G. T. Chandler, Manager

Materials Performance and Corrosion Tech.

Materials Technology Section

Date:

N. C. Iyer, Manger

Materials Technology Section

Savannah River National Laboratory 
Revision 0

\section{Table of Contents}

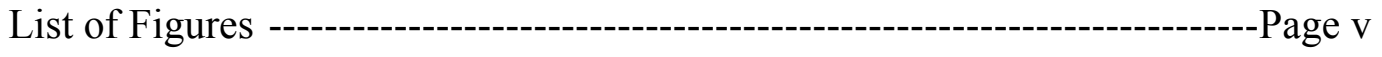

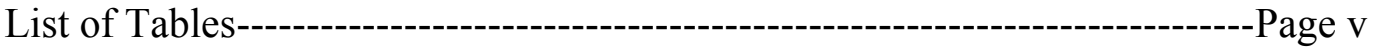

Summary-------------------------------------------------------------------------------Page 1

Introduction -----------------------------------------------------------------------------Page 2

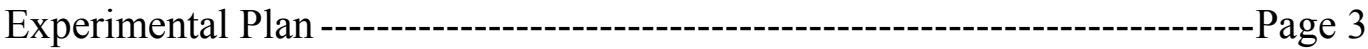

Series One - Non-Polarized U-Bend Testing----------------------------------Page 3

Series Two - Polarized U-Bend Testing -------------------------------------Page 6

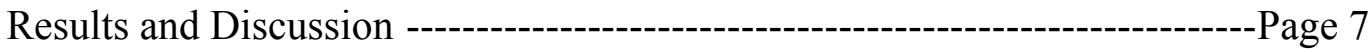

Series One - Non-Polarized U-Bend Testing---------------------------------Page 7

Series Two - Polarized U-Bend Testing --------------------------------------- Page10

Conclusions ------------------------------------------------------------------------- Page 13

Acknowledgements --------------------------------------------------------------- Page 14

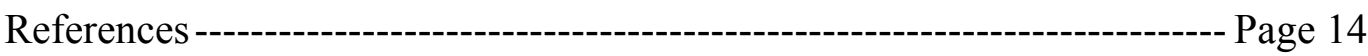

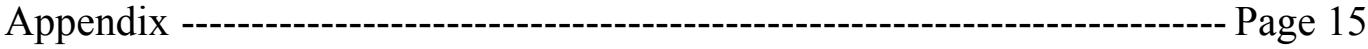


WSRC-STI-2007-00552

Revision 0

\section{List of Figures}

Figure 1. Prepared Non-Polarized Coupons, and Positions in Test Vessel ..................... 4

Figure 2. Prepared Polarized U-Bend Specimen, Before Bolt Tightened ....................... 6

Figure 3. Typical Appearance of U-Bend after 100 Days in Simulant.......................... 8

Figure 4. OCP Data for LAI U-Bends in 8.5 M Nitrate Solution with Reduced Inhibitor Levels.............. 9

Figure 5. OCP Data for LAIU-Bends in 5.5 M Nitrate Solution with Reduced Inhibitor Levels ............. 10

Figure 6. Polarized U-Bend After 80 Days in Test.................................................. 11

Figure 7 Polarized U-Bends After Initial Cleaning .................................................. 11

Figure 8. Current Response of Polarized U-bend in $5.5 \mathrm{MNO}_{3}^{-}$, Low Inhibitors, $50^{\circ} \mathrm{C} \ldots \ldots \ldots \ldots \ldots \ldots \ldots . . . . . . . . . . .12$

Figure 9. Current Response of Polarized U-bend in 7.0 $\mathrm{MNO}_{3}^{-}$, Low Inhibitors, $50^{\circ} \mathrm{C} \ldots \ldots \ldots \ldots \ldots \ldots \ldots \ldots . . . . . . . . .12$

Figure 10. Current Response of Polarized U-bend in 7.0 $\mathrm{MNO}_{3}^{-}$, Med. Inhibitors, $50^{\circ} \mathrm{C} . \ldots \ldots \ldots \ldots \ldots \ldots \ldots . . . . . . . . . . . .13$

\section{List of Tables}

Table 1. Long-Term, Unpolarized U-Bend Tests in VS and LAI Regions, $50^{\circ} \mathrm{C} \ldots \ldots \ldots \ldots . . .5$

Table 2. Low Concentration Chemical Constituents Used in Test Solutions ................... 5

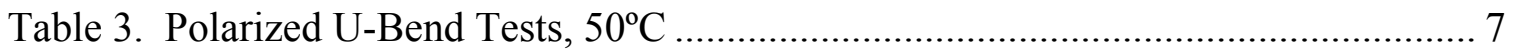

Table 4. Open Circuit Potential of U-Bends on Day 1 and Day 100 of Testing .............. 8

Table 5. Description of Non-Polarized U-Bends After 100 Days in Test ..................... 15 


\section{Summary}

Preparation of high level waste for vitrification involves in part the dissolution of salt cake from the carbon steel storage tanks. During dissolution, a point is reached in which the corrosion inhibitors, hydroxide and nitrite, are diluted below established guidelines, and nitrate stress corrosion cracking (SCC) is possible. Because the addition of inhibitors may be counterproductive to process efficiency and waste minimization, corrosion testing was initiated to revisit and possibly revise the guidelines for inhibitor limits. The bases for the work summarized in this status report are results from previously-completed phases of study.

In the first two phases of study, several reduced-inhibitor levels were tested in HLW simulants with nitrate concentrations ranging from 4.5 M to $8.5 \mathrm{M}$. The first two phases of work determined, among other things, the reduced-inhibitor levels and solution chemistries in which heat-treated and non-heat-treated A537 carbon steel is susceptible to SCC, crevice corrosion, and pitting. The work covered in this current task both builds on and verifies the conclusions of the previous work. The current work involves testing of low levels of inhibitors in HLW simulants with $5.5 \mathrm{M}$ to $8.5 \mathrm{M}$ nitrate concentrations. Stressed U-bend specimens, both polarized and non-polarized, were tested.

Non-polarized U-bend testing is ongoing, with the U-bends currently in test for 100 days. The purpose of the testing is to determine SCC susceptibility in the vapor space (VS) and liquid air interface (LAI) regions of the HLW tanks under conditions expected during salt dissolution, and also to verify previous accelerated testing. The simulated wastes being tested have nitrate concentrations of 5.5 $\mathrm{M}$ and $8.5 \mathrm{M}$ and inhibitor levels of $0.01 \mathrm{M} / 0.01$ $\mathrm{M}$ hydroxide/nitrite and $0.1 \mathrm{M} / 0.1 \mathrm{M}$ hydroxide/nitrite. The open circuit potential measurements being monitored and the corrosion morphology of the U-bends are in agreement with results and observations of previous phases of work. No SCC has occurred in the first 100 days of testing. The LAI specimens experienced minor corrosion at the liquid line with corrosion products visible on the weld material and in the heat-affected zones on either side of the welds. The VS specimens are more evenly and slightly more corroded.

Polarized U-bend testing is complete after approximately 80 days of testing. No SCC occurred, but the results are inconclusive due to a competing, unexpected galvanic corrosion mechanism that interfered in the last 50 days of testing. No cracking was indicated during the first month. The tests will be repeated in order to satisfy the original objective which was to determine the effect of grinding HLW tank welds and heattreating the tanks had on corrosion.

Both the non-polarized and polarized U-bend tests will continue. Additionally, cyclic polarization (CP) testing will be performed to examine the effects of surface oxides on corrosion and the differences in corrosion susceptibility between welded and un-welded areas. 


\section{Introduction}

High-level waste is stored at SRS in large underground tanks constructed of carbon steel. Preparation of the waste for vitrification involves in part the dissolution of salt cake that has accumulated in the tanks so that it may be transferred to the Saltstone Facility. The salt crystals composing this cake have a high nitrate concentration and therefore have the potential to be corrosive to the carbon steel once dissolved. Stress corrosion cracking (SCC) is the primary corrosion mechanism of concern.

The interstitial liquid in equilibrium with the crystals in the salt cake tends to be rich in hydroxide and nitrite, both of which inhibit the corrosive nature of the nitrate solution. During the salt dissolution process, however, a stage is reached in which the inhibitors are insufficient to prevent the initiation of corrosion. Although an administrative control program [1] is in place that requires the addition of inhibitors to the dissolution water, it has been determined that the additions can negatively impact process efficiency and waste minimization. Because of these potential liabilities, the basis for the corrosion control limits is being revisited. The desire is to determine the risks associated with operating at lower inhibitor concentrations for the short period of time when dissolution occurs.

To this end, corrosion testing was previously completed on phases one and two of Task Technical Plan (TTP) SRNL-MTS-2005-50019 [2]. The results of these tests are contained in draft report WSRC-STI-2006-00029 [3]. The previous work identified susceptibility to SCC, characterized pitting resistance and determined general corrosion rates under reduced inhibitor conditions. It also assessed the effects of inhibitor concentration and heat treatment on SCC and determined parameters for future SCC testing.

This status report covers two series of tests that build on the previous work. The work is outlined in TTP WSRC-STI-2007-00218 [4]. Currently in progress is series one consisting of polarized (accelerated) and non-polarized U-bend testing. The objectives of the non-polarized U-bend tests are to study the effects of time on SCC susceptibility, verify results of previous accelerated testing and also characterize SCC effects in the vapor space (VS) and liquid/air interface (LAI) regions in the tanks. The objective of the polarized tests is to determine the effect that welding, weld grinding, and heat treating had on the tank in regards to SCC susceptibility.

Series two will involve electrochemical cyclic polarization (CP) testing to study the effects of surface oxides on corrosion and the differences in corrosion susceptibility between welded and un-welded areas. 
WSRC-STI-2007-00552

October 2007

Revision 0

Page 3 of 15

\section{Experimental Plan}

\section{Series One-Non-Polarized U-Bend Testing}

The objectives of the non-polarized U-bend tests are to study the effects of time on SCC susceptibility, verify results of previous accelerated testing and characterize SCC effects in the vapor space (VS) and liquid/air interface (LAI) regions in the tanks. Pitting corrosion in these regions was previously characterized by exposing unstressed (non-Ubend) coupons. The results suggested that the combination of mill-scale and the deliquescent behavior of hydroxide provided sufficient protection in the LAI region, and defects in the mill-scale on coupons in the VS region provided possible points of minor pit initiation and growth $[5,6]$. The current tests will determine if heat treatment provides the same protection against SCC in these regions and also whether pit initiation will lead to SCC in the VS region of the tank.

The ongoing non-polarized U-bend testing consists of eight pairs of A537 carbon steel Ubend coupons exposed to three different salt solution chemistries. Four of the pairs were heat-treated to simulate the stress relief given to the Type III/IIIA waste tanks. One Ubend coupon in each pair is exposed completely in the vapor region and one is exposed partially-immersed in the simulated waste solution. The test vessels are wide-mouthed polyethylene bottles filled with approximately $500 \mathrm{ml}$ of solution and placed in an oven to obtain the test temperature of $50{ }^{\circ} \mathrm{C}$. Evaporative losses from the solution are replaced by distilled water.

All U-bends came from the same heat of material as specimens used in the previous work, and they were fabricated in the same manner, with a butt weld traveling in the long transverse-longitudinal orientation [3]. Four of the eight U-bend pairs were heat treated in air. They were heated from ambient to $1100^{\circ} \mathrm{F}$ at a rate of $90^{\circ} \mathrm{F} /$ hour, followed by a hold at $1100^{\circ} \mathrm{F}$ for 60 minutes, and a cooling rate of $115^{\circ} \mathrm{F} / \mathrm{hr}$ to ambient [3].

Indentations were then placed in the oxide film on the surface of six pairs of the U-bends, with one pair each of the heat-treated and non-heat-treated U-bends left without indentations. A wire was attached to the side of each LAI coupon with conductive silver epoxy and the silver epoxy then coated with inert mounting material. The wire on the LAI coupon allowed for measurement of electrical potential referenced against a silver silver-chloride electrode also immersed in the solution. Stress was applied to each Ubend by tightening the bolt positioned through the ends of the U-bend arms. The arms were tightened until parallel with each other.

All U-bends were coated with test salt solution and then allowed to dry so that salt crystals formed on the surfaces, to simulate conditions in the vapor space of the waste tanks. Simulant was dropped onto the stressed area of each U-bend using a pipette, and the simulant was dried on the surface using compressed air. The U-bends were then located in their respective positions in the vapor space and at the liquid-air interface in the test vessel. Figure 1 shows the prepared coupons and their respective positions in the test vessel. 


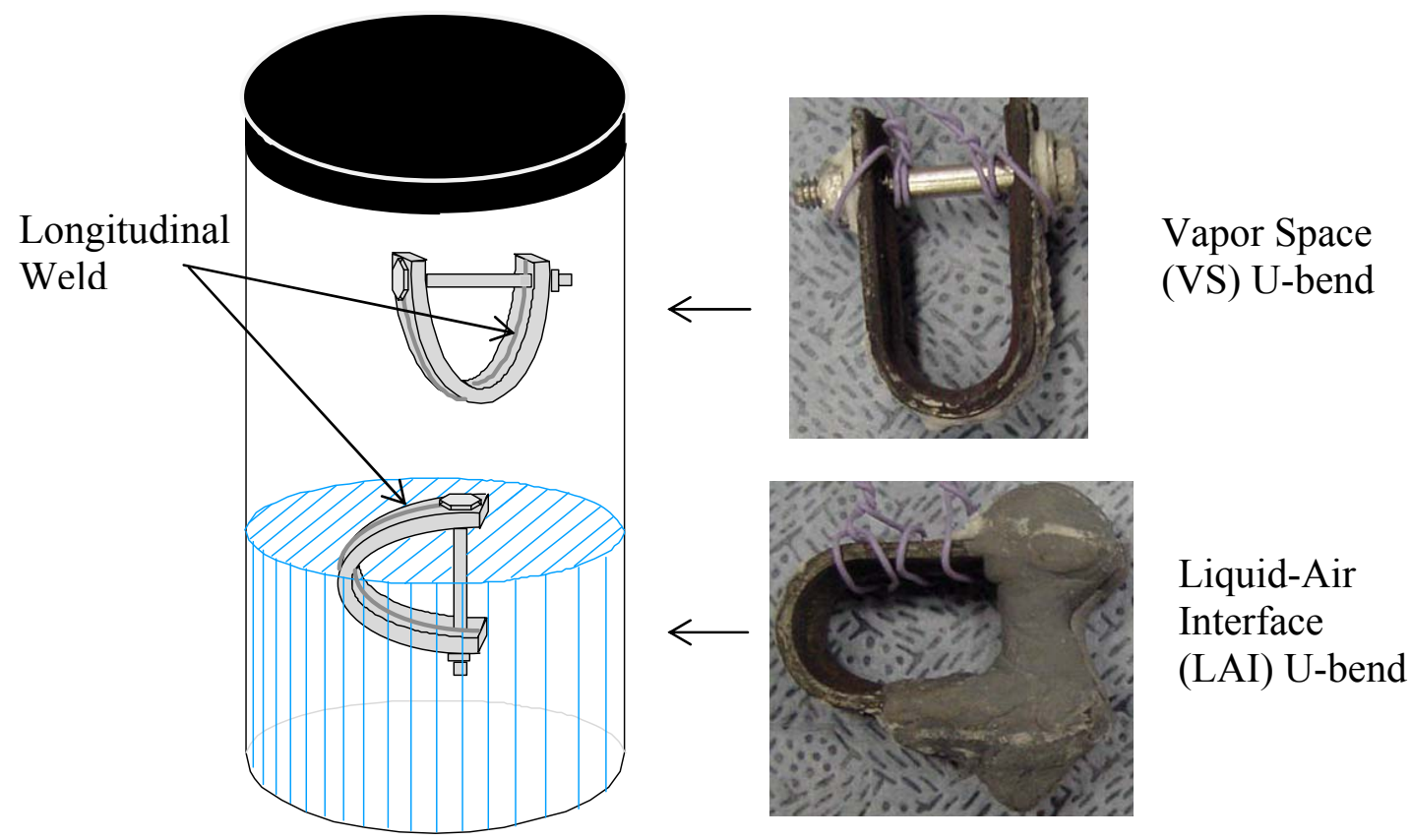

Figure 1. Prepared Non-Polarized Coupons, and Positions in Test Vessel

The U-bend specimens are being exposed to three different salt solution chemistries. Two of the salt solutions contain the lowest inhibitor level used in the previous experiments along with either $5.5 \mathrm{M}$ nitrate or $8.5 \mathrm{M}$ nitrate concentrations. The $8.5 \mathrm{M}$ nitrate solution is the highest nitrate level previously tested. The third solution is $8.5 \mathrm{M}$ nitrate with a medium level of inhibitors present. The experimental test conditions are shown in Table 1. All solutions also contain the constituents listed in Table 2.

These U-bend coupons are not being polarized. The equilibrium or open circuit potential (OCP) of each LAI coupon is being measured against an $\mathrm{Ag} / \mathrm{AgCl}$ reference electrode placed in the salt solution. The monitoring is being done to determine how long it takes for the specimen potential to enter an SCC-prone region and also measure the potential at which SCC does occur. The OCP measurements are being taken and recorded for a 40 minute period, approximately twice a week. The measurements are being taken by a Gamry potentiostat model PC4-750. In between measurements, the coupons are being examined periodically for cracking, with none being found. The testing period has lasted approximately 100 days. Testing will continue for a few more weeks as planned but may be extended if cracking has not occurred. Final results of the testing will be analyzed and compared to the results from phase two of the previous experiments [3]. 
WSRC-STI-2007-00552

Table 1. Long-Term, Unpolarized U-Bend Tests in VS and LAI Regions, $5^{\circ} \mathrm{C}$

\begin{tabular}{|c|c|c|c|c|c|c|}
\hline \multirow{2}{*}{$\begin{array}{l}\text { Test } \\
\text { No. }\end{array}$} & \multirow[t]{2}{*}{ U-bend Prep. } & \multirow{2}{*}{$\begin{array}{l}\text { U-bend } \\
\text { Location }\end{array}$} & \multirow{2}{*}{$\begin{array}{l}\text { Electrochem. } \\
\text { Data }\end{array}$} & \multicolumn{3}{|c|}{ General Solution Chemistries } \\
\hline & & & & $\begin{array}{l}\text { Nitrate } \\
\text { (M) }\end{array}$ & $\begin{array}{l}\text { Nitrite } \\
\text { (M) }\end{array}$ & $\begin{array}{l}\text { Hydroxide } \\
\text { (M) }\end{array}$ \\
\hline \multirow[t]{2}{*}{ A } & $\begin{array}{l}\text { As received, } \\
\text { indent }\end{array}$ & LAI & $\begin{array}{c}\text { Measure } \\
\text { OCP }\end{array}$ & 5.5 & 0.01 & 0.01 \\
\hline & $\begin{array}{l}\text { As received, } \\
\text { indent }\end{array}$ & VS & None & 5.5 & 0.01 & 0.01 \\
\hline \multirow[t]{2}{*}{ B } & $\begin{array}{c}\text { As received, } \\
\text { heat treat, indent }\end{array}$ & LAI & $\begin{array}{c}\text { Measure } \\
\text { OCP }\end{array}$ & 5.5 & 0.01 & 0.01 \\
\hline & $\begin{array}{c}\text { As received, } \\
\text { heat treat, indent }\end{array}$ & VS & None & 5.5 & 0.01 & 0.01 \\
\hline \multirow[t]{2}{*}{$\mathrm{C}$} & $\begin{array}{l}\text { As received, } \\
\text { indent }\end{array}$ & LAI & $\begin{array}{c}\text { Measure } \\
\text { OCP }\end{array}$ & 8.5 & 0.01 & 0.01 \\
\hline & $\begin{array}{c}\text { As received, } \\
\text { indent }\end{array}$ & VS & None & 8.5 & 0.01 & 0.01 \\
\hline \multirow[t]{2}{*}{$\mathrm{D}$} & $\begin{array}{c}\text { As received, } \\
\text { heat treat, indent }\end{array}$ & LAI & $\begin{array}{c}\text { Measure } \\
\text { OCP } \\
\end{array}$ & 8.5 & 0.01 & 0.01 \\
\hline & $\begin{array}{c}\text { As received, } \\
\text { heat treat, indent }\end{array}$ & VS & None & 8.5 & 0.01 & 0.01 \\
\hline \multirow[t]{2}{*}{ E } & $\begin{array}{l}\text { As received, } \\
\text { indent }\end{array}$ & LAI & $\begin{array}{c}\text { Measure } \\
\text { OCP }\end{array}$ & 8.5 & 0.1 & 0.1 \\
\hline & $\begin{array}{c}\text { As received, } \\
\text { indent }\end{array}$ & VS & None & 8.5 & 0.1 & 0.1 \\
\hline \multirow[t]{2}{*}{$\mathrm{F}$} & $\begin{array}{c}\text { As received, } \\
\text { heat treat, indent }\end{array}$ & LAI & $\begin{array}{c}\text { Measure } \\
\text { OCP }\end{array}$ & 8.5 & 0.1 & 0.1 \\
\hline & $\begin{array}{c}\text { As received, } \\
\text { heat treat, indent }\end{array}$ & VS & None & 8.5 & 0.1 & 0.1 \\
\hline \multirow[t]{2}{*}{ G } & As received & LAI & $\begin{array}{c}\text { Measure } \\
\text { OCP }\end{array}$ & 8.5 & 0.01 & 0.01 \\
\hline & As received & VS & None & 8.5 & 0.01 & 0.01 \\
\hline \multirow[t]{2}{*}{$\mathrm{H}$} & $\begin{array}{l}\text { As received, } \\
\text { heat treat }\end{array}$ & LAI & $\begin{array}{l}\text { Measure } \\
\text { OCP }\end{array}$ & 8.5 & 0.01 & 0.01 \\
\hline & $\begin{array}{l}\text { As received, } \\
\text { heat treat }\end{array}$ & VS & None & 8.5 & 0.01 & 0.01 \\
\hline
\end{tabular}

Table 2. Low Concentration Chemical Constituents Used in Test Solutions

\begin{tabular}{|c|c|}
\hline Chemical & Concentration (M) \\
\hline $\mathrm{NaAlO}_{2}$ & 0.5 \\
\hline $\mathrm{Na}_{2} \mathrm{CO}_{3}$ & 0.1 \\
\hline $\mathrm{Na}_{2} \mathrm{SO}_{4}$ & 0.1 \\
\hline $\mathrm{Na}_{2} \mathrm{HPO}_{4} \mathrm{X}_{7 \mathrm{H} 2 \mathrm{O}}$ & 0.05 \\
\hline $\mathrm{NaCl}$ & 0.1 \\
\hline
\end{tabular}


WSRC-STI-2007-00552

Series Two-Polarized U-Bend Testing

Three polarized U-bend tests were completed. They differed from previous experiments in that the weld on each U-bend surface was ground flat prior to heat treatment and immersion in simulated waste solution. The objective of the polarized tests was to simulate the methods used in constructing the waste tanks.

The polarized testing consisted of three A537 carbon steel U-bend coupons exposed to three different salt solution chemistries. All U-bend coupons came from the same heat of material as specimens used in previous work [3]. All coupons had the weld bead on the outside of each U-bend ground flat, and the specimens were then heat-treated to simulate the treatment given to the Type III/IIIA waste tanks prior to their use. Indentations were placed in the oxide film on the surface of the U-bends. A wire was attached to the side of each specimen with conductive silver epoxy, and the silver epoxy then coated with inert mounting material. Stress was applied to the U-bends by tightening the bolt positioned through the ends of the U-bend arms. The arms were tightened until parallel with each other. An example of a prepared specimen is shown in Figure 2. The stressed end of each U-bend was immersed in simulated waste solution and the U-bend was polarized. The test vessels were wide-mouthed polyethylene bottles filled with approximately 500 $\mathrm{ml}$ of solution and placed in an oven to obtain the test temperature of $50{ }^{\circ} \mathrm{C}$. Evaporative losses from the solution were replaced by distilled water.

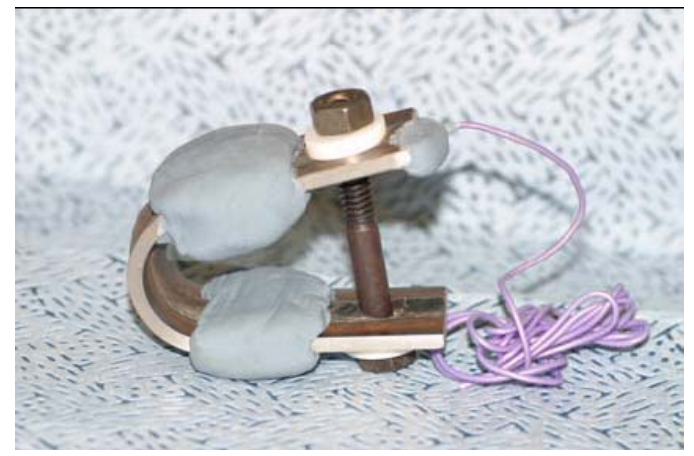

Figure 2. Prepared Polarized U-Bend Specimen, Before Bolt Tightened

Two of the salt solutions tested contained the lowest inhibitor level used in the previous experiments with 5.5 $\mathrm{M}$ nitrate and 7.0 $\mathrm{M}$ nitrate. The third solution was $7.0 \mathrm{M}$ nitrate with a medium level of inhibitors present. The experimental test conditions are shown in Table 3. All solutions also contained the constituents listed in Table 2.

Potentiostatic polarization was conducted by applying a constant potential to the working electrode (U-bend) and monitoring the responding current. A potential of zero volts versus the $\mathrm{Ag} / \mathrm{AgCl}$ reference electrode was chosen to bring each specimen into a possible range for SCC, as determined in the previous phases of testing [3]. Each setup consisted of an $\mathrm{Ag} / \mathrm{AgCl}$ reference electrode, a graphite counter electrode, and a stressed polarized U-bend. A Gamry electrochemical multiplexer, model ECM8 and a Gamry 
potentiostat model PC4-750 were used for continuous polarization of the multiple samples. The current response was recorded throughout the experiment, which lasted 86 days.

During testing, the coupons were visually examined for cracking, although corrosion products obscured the surface. The specimen arms were also gently squeezed to feel if the stress had relieved through cracking. Results of the testing were analyzed and compared to the results from phase two of the previous experiments, which used U-bends with un-ground welds [3].

Table 3. Polarized U-Bend Tests, $5^{\circ} \mathrm{C}$

\begin{tabular}{|c|c|c|c|c|c|c|}
\hline Test & U-bend Prep. & $\begin{array}{c}\text { U-bend } \\
\text { Location }\end{array}$ & \multirow{2}{*}{$\begin{array}{c}\text { Electrochem. } \\
\text { Data }\end{array}$} & \multicolumn{3}{|c|}{ General Solution Chemistries } \\
\cline { 4 - 7 } & & $\begin{array}{c}\text { Nitrate } \\
(\mathrm{M})\end{array}$ & $\begin{array}{c}\text { Nitrite } \\
(\mathrm{M})\end{array}$ & $\begin{array}{c}\text { Hydroxide } \\
(\mathrm{M})\end{array}$ \\
\hline $\mathrm{G}$ & $\begin{array}{c}\text { Grind weld flat, } \\
\text { heat treat }\end{array}$ & Immersed & $\begin{array}{c}\text { Polarize, } \\
\text { Measure } \\
\text { Current }\end{array}$ & 5.5 & 0.01 & 0.01 \\
\hline $\mathrm{H}$ & $\begin{array}{c}\text { Grind weld flat, } \\
\text { heat treat }\end{array}$ & Immersed & $\begin{array}{c}\text { Polarize, } \\
\text { Measure } \\
\text { Current }\end{array}$ & 7.0 & 0.01 & 0.01 \\
\hline $\mathrm{J}$ & $\begin{array}{c}\text { Grind weld flat, } \\
\text { heat treat }\end{array}$ & Immersed & $\begin{array}{c}\text { Polarize, } \\
\text { Measure } \\
\text { Current }\end{array}$ & 7.0 & 0.1 & 0.1 \\
\hline
\end{tabular}

\section{Results and Discussion}

\section{Series One-Non-Polarized U-Bend Testing}

No stress corrosion cracking occurred in the non-polarized U-bend testing during the first 100 days of exposure. Determination of whether SCC occurred was made by visual examination and also by gently squeezing the arms of each U-bend to determine if stress was relieved through cracking. Figure 3 shows the typical appearance of the specimens after 100 days in test. Table 5 in the Appendix contains details from visual examination of the specimens. 

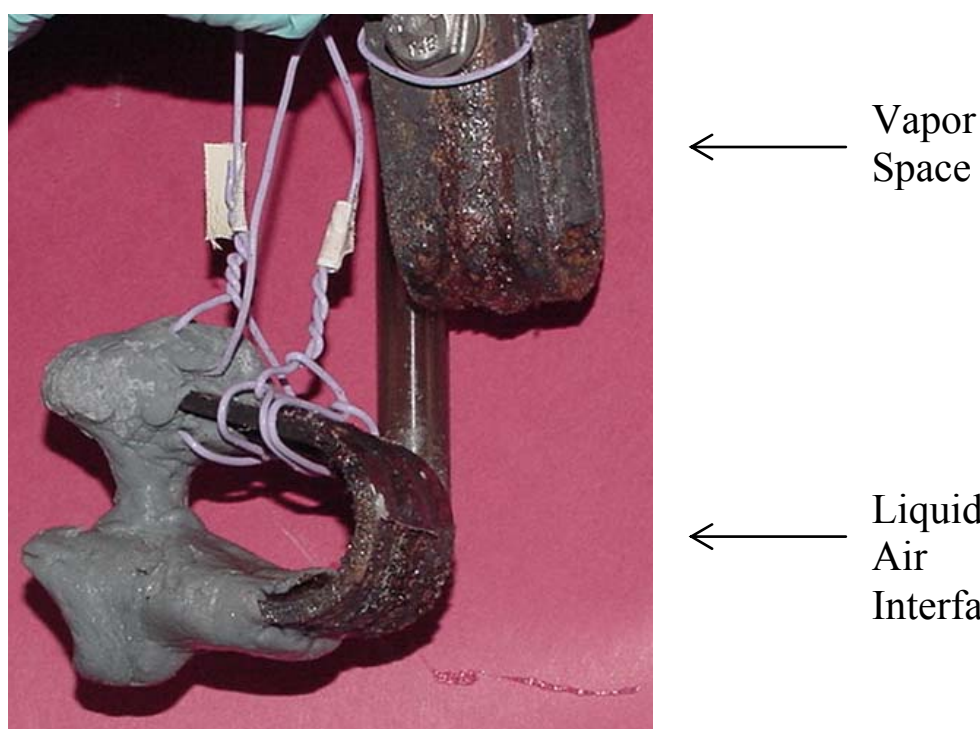

Liquid-

Air

Interface

Figure 3. Typical Appearance of U-Bend after 100 Days in Simulant

Open-circuit potential (OCP) data was collected twice a week from each of the eight Ubends located at the liquid-air interface of the test solutions. Table 4 contains the initial OCP and the final OCP measured after 100 days of exposure. The OCP increased over time for all eight LAI U-bends, becoming more electropositive. Increases in OCP may indicate that the specimens are reacting to their environment and are entering a region of potential in which they are more susceptible to corrosion, or it could indicate that the chemistry at the surfaces of the coupons is changing. The closer the OCP climbs to the repassivation $\mathrm{E}_{\mathrm{rp}}$ potential, for instance, the more likely crevice corrosion is, and when the OCP climbs higher than the breakdown potential $\left(\mathrm{E}_{\mathrm{b}}\right)$, the stressed specimens become susceptible to pitting and stress corrosion cracking.

Table 4. Open Circuit Potential of U-Bends on Day 1 and Day 100 of Testing

\begin{tabular}{|l|l|l|r|r|}
\hline $\begin{array}{c}\text { Inhibitor } \\
\text { Level }\end{array}$ & \multicolumn{1}{|c|}{$\begin{array}{c}\text { Nitrate } \\
(\mathrm{M})\end{array}$} & \multicolumn{1}{c|}{$\begin{array}{c}\text { Heat } \\
\text { Treatment }\end{array}$} & $\begin{array}{c}\text { Initial OCP } \\
(\mathrm{mV})\end{array}$ & $\begin{array}{c}\text { 100-day OCP } \\
(\mathrm{mV})\end{array}$ \\
\hline Low & 5.5 & No & -332 & -254 \\
\hline Low & 5.5 & Yes & -305 & -249 \\
\hline Low & 8.5 & No & -309 & -240 \\
\hline Low & 8.5 & Yes & -326 & -207 \\
\hline Low & 8.5 & No* & -312 & -166 \\
\hline Low & 8.5 & Yes* & -310 & -182 \\
\hline Medium & 8.5 & No & -305 & -176 \\
\hline Medium & 8.5 & Yes & -283 & \\
\hline
\end{tabular}

*These did not receive indenting to determine if indenting had any effect on results. 
The conditions in the first row of Table 4 were used in the previously-completed first phase of testing [3], with OCP measurements being made on a non-stressed coupon immersed in solution for one week. The initial and final OCP measurements were -308 and $-106 \mathrm{mV}$. The initial potential measurement for this test is similar to the initial test result in Table 4 (-332). In comparing the final OCP measurements, however, the specimen from the formerly completed test is significantly more electropositive, and became so more quickly. The coupon had a bare metal surface free of any mill scale and was more reactive with the waste simulant, which leads to greater oxidation.

The OCP data for the ongoing tests are being collected for 40 minutes at a time, approximately twice a week. The averages for each 40-minute period during the first 100 days are plotted in Figure 4 and Figure 5.

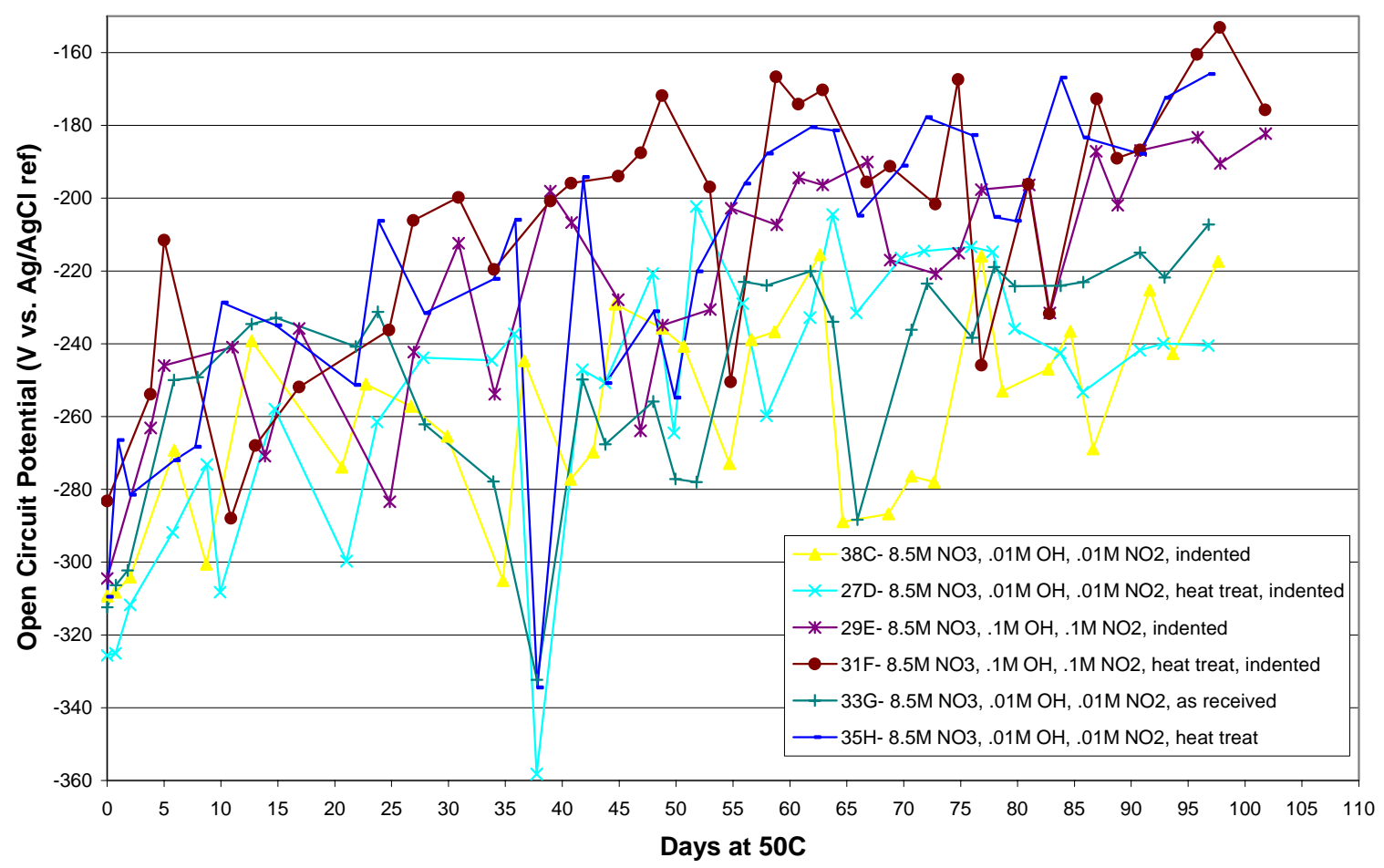

Figure 4. OCP Data for LAI U-Bends in 8.5 M Nitrate Solution with Reduced Inhibitor Levels 


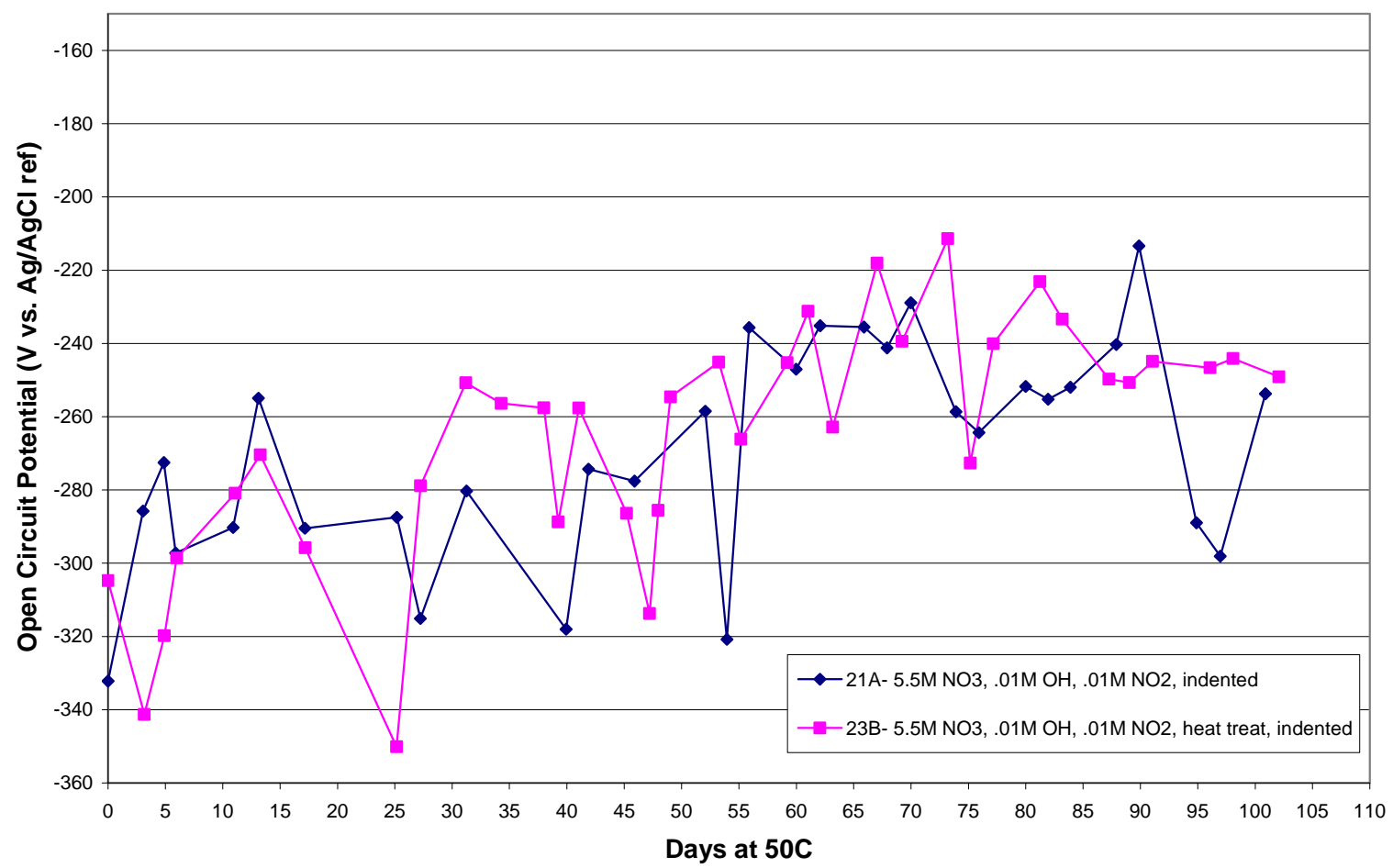

Figure 5. OCP Data for LAI U-Bends in 55 M Nitrate Solution with Reduced Inhibitor Levels

From previous CPP testing on polished samples and samples immersed for a week in solution [3], it was expected that the initial OCP would not have a dependence on nitrate concentration or inhibitor level. The current data agrees with that conclusion. The initial open circuit potentials range from -283 to $-330 \mathrm{~V}$ which are similar to initial potentials of U-bends in previous tests which ranged from -325 to $-400 \mathrm{~V}$ for $8.5 \mathrm{M}$ and $5.5 \mathrm{M}$ tests [3]. The U-bends in the medium inhibitor $8.5 \mathrm{M}$ solution have higher final potentials than the U-bends in the low inhibitor $8.5 \mathrm{M}$ solution, given the same heat treat status. This too is in line with previous CPP data which indicated that the final OCP had a slight dependence on inhibitor level [3]. Figures 4 and 5 reveal no clear difference in OCP between the heat-treated and non-heat-treated U-bends. This was the case for initial OCP measurements of U-bends in previous testing [3].

\section{Series Two-Polarized U-Bend Testing}

No stress corrosion cracking occurred during three polarized U-bend tests. The results, however, were inconclusive because an unforeseen galvanic couple developed between the bolts supplying the stress to each U-bend and the U-bends themselves. The additional corrosion mechanism had a significant effect during the last half of testing. Plots of the current response data from the polarized U-bends were analyzed to determine, if possible, when the interference became significant. The U-bends were also visually examined to determine whether cracking occurred in the stressed area of each specimen. 
The U-bends quickly acquired thick layers of oxides and corrosion products that obscured the metal surfaces. This occurred within two to three weeks. Figure 6 is a picture of an encrusted U-bend at the end of testing. Figure 7 shows the U-bends after initial cleaning.

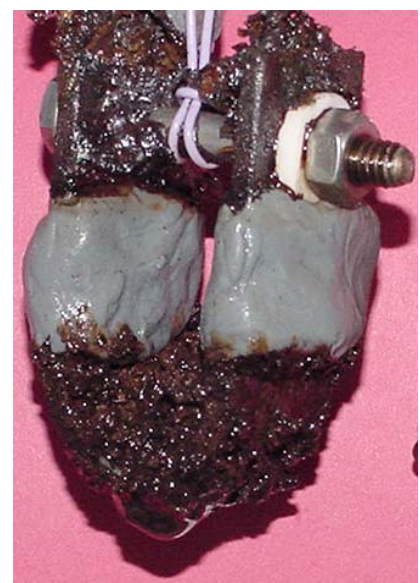

Figure 6. Polarized U-Bend After 80 Days in Test

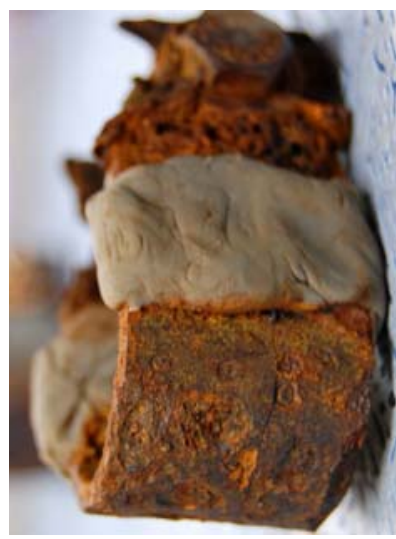

5.5 M Nitrate Low Inhibitor

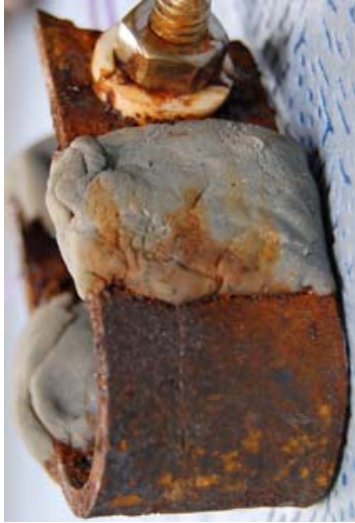

7.0 M Nitrate Low Inhibitor

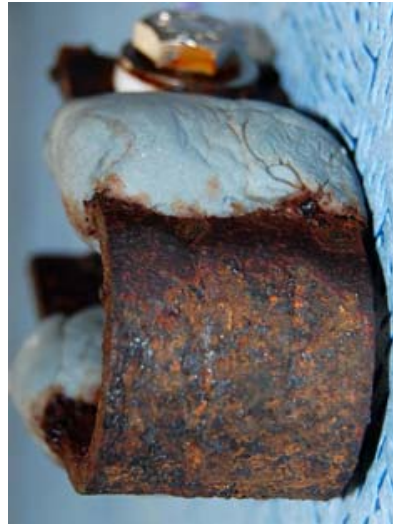

7.0 M Nitrate Medium Inhibitor

Figure 7 Polarized U-Bends After Initial Cleaning

The condition of the U-bends is the result of both the polarization and the galvanic corrosion between the stainless steel bolts and the carbon steel U-bends. The bolt on each U-bend was cathodic to the carbon steel and caused the anodic U-bend to corrode. This corrosion was strongest near the bolts.

Visual examination of the stressed (bent) portions of the U-bends at $10 \mathrm{X}$ revealed no stress corrosion cracking. The specimen in the $5.5 \mathrm{M}$ nitrate, low inhibitor solution exhibited severe pitting and general corrosion with significant thinning of the metal. The specimen in the 7.0 M nitrate, low inhibitor solution was in better condition, with no thinning but also had pitting and general corrosion. Lastly, the specimen in the $7.0 \mathrm{M}$ 
nitrate, medium inhibitor solution was in the best condition of the three, again with no signs of cracking.

Polarization of the U-bends took place for a period of time, but diminished and eventually stopped as galvanic corrosion products built up under the wire connecting the U-bend to the potentiostat. The current response from each U-bend was recorded during polarization. Graphs of the first month's data for each U-bend are shown in Figures 8-10.

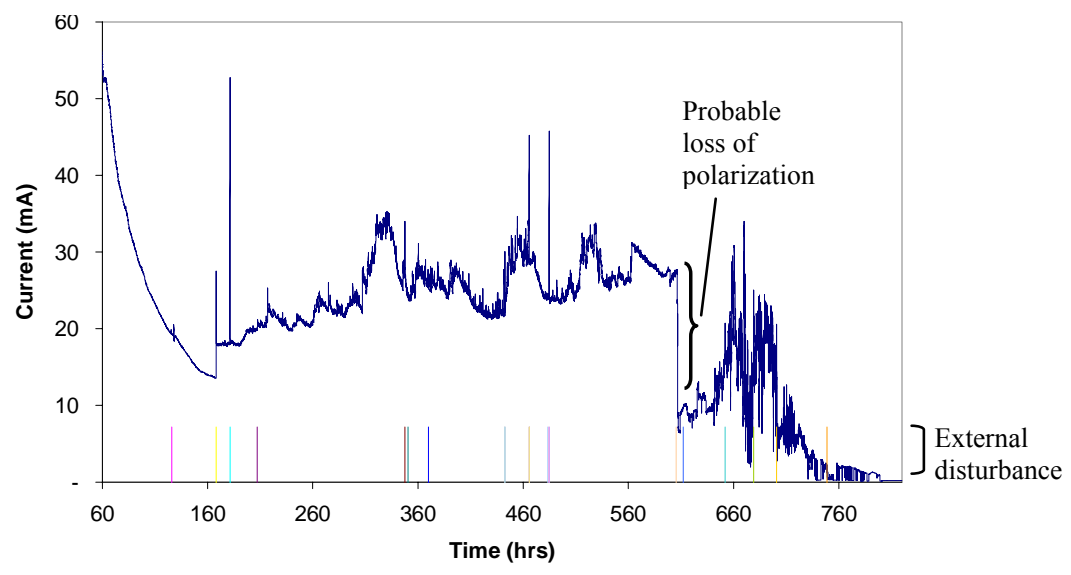

Figure 8. Current Response of Polarized U-bend in $5.5 \mathrm{M} \mathrm{NO}_{3}^{-}$, Low Inhibitors, $50^{\circ} \mathrm{C}$

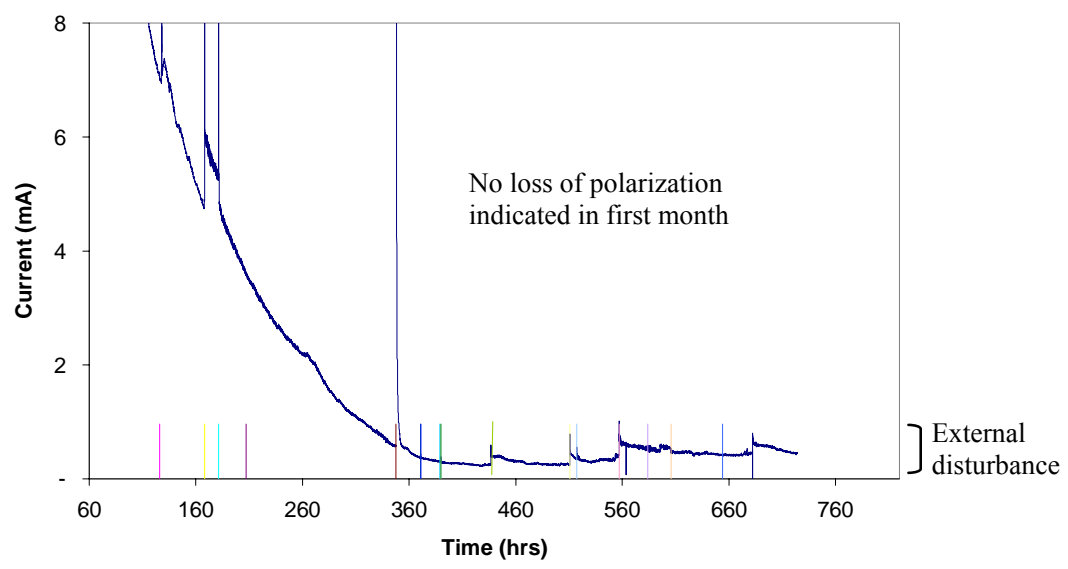

Figure 9. Current Response of Polarized U-bend in 7.0 $\mathrm{MNO}_{3}^{-}$, Low Inhibitors, $50^{\circ} \mathrm{C}$ 


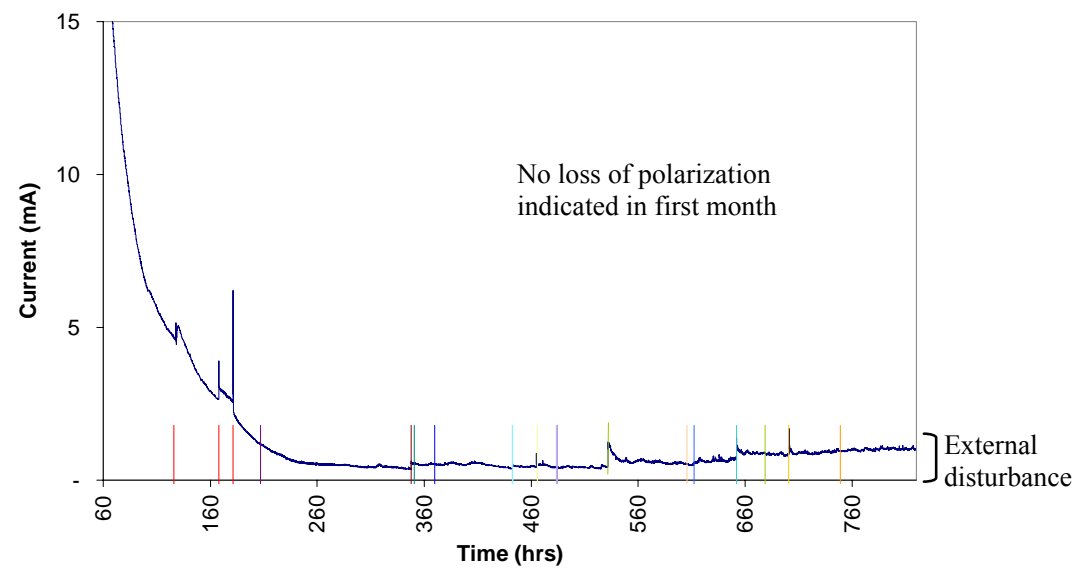

Figure 10. Current Response of Polarized U-bend in 7.0 M NO${ }_{3}^{-}$, Med. Inhibitors, $50^{\circ} \mathrm{C}$

The current response data for the U-bend in the 5.5 M nitrate solution with low inhibitor levels indicates that interference problems were experienced after one week in solution and that loss of contact with the potentiostat may have occurred in the fourth week. The other U-bends, in 7.0 M nitrate solutions with low and medium inhibitor levels, did not appear to lose contact with the potentiostat during the first month of testing. The current response from these specimens did not indicate any significant corrosion events during that time period. Due to the uncertain nature of the tests and the abbreviated data, fresh specimens will be exposed under the same conditions to obtain clearer results. The galvanic current will be eliminated by ensuring no contact between bolt and coupon.

\section{Conclusions}

No stress-corrosion cracking of U-bend specimens has occurred during the two series of tests described in this report. The non-polarized U-bend tests are progressing beyond 100 days and will continue until: 1) stress corrosion cracking occurs or until 2) there is no significant change in OCP and no additional corrosion is likely to occur. The OCP data collected have verified the results of previous accelerated tests:

- Initial OCP does not have a dependence on nitrate concentration or inhibitor level.

- The dependence of OCP on inhibitor level increases over time.

- Initial OCP does not have a dependence on whether a specimen is heat treated.

Additionally, the non-polarized tests will provide evidence as to whether there is increased SCC susceptibility at the liquid-air interface and whether stressed specimens in the vapor region could experience SCC under reduced-inhibitor conditions.

No SCC occurred during the first month of testing three polarized, heat-treated U-bends. The U-bends were tested for three months, but results were inconclusive beyond one month due to competing, galvanic corrosion occurring on the specimens. In previous experiments under the same conditions [3], no cracking occurred on heat-treated specimens during 18 weeks of polarization. The tests covered in this report differ from 
previous tests in that the U-bends had their welds ground flat prior to heat treatment. The experiments will be repeated in order to fulfill the objectives of verifying the previous results and determining the effect that HLW tank preparation techniques, i.e. weld grinding and then heat-treating, have on SCC susceptibility.

\section{Acknowledgements}

The authors want to express their gratitude to Delinda Williams for performing, organizing, and documenting the testing. The authors also acknowledge the efforts of the reviewers in the preparation of this report.

\section{References}

1. "CSTF Corrosion Control Program: Program Description Document", WSRCTR-2002-00327, Rev. 3, November 17, 2004.

2. B. J. Wiersma, "Task Plan for the Determination of Corrosion Inhibitor Criteria for Type III/IIIA Tanks During Salt Dissolution Operations", SRNL-MTS-200550019, August 10, 2005.

3. B. J. Wiersma, J. I. Mickalonis, "Determination of Corrosion Inhibitor Criteria for Type III/IIIA Tanks During Salt Dissolution Operations (U)”, WSRC-STI-200600029, DRAFT, November, 2006.

4. K. M. Counts, B. J. Wiersma, J. I. MIckalonis, "Task Plan for the Determination of Corrosion Inhibitor Criteria for Type III/IIIA Tanks During Salt Dissolution Operations - Additional Testing”, WSRC-STI-2007-00218, May 7, 2007.

5. K. H. Subramanian and P. E. Zapp, "Vapor Space and Liquid/Air Interface Corrosion Tests of Low Carbon Steel”, WSRC-TR-2002-00471, November, 2002.

6. K. H. Subramanian, "Pitting in the Vapor Space and Liquid/Air Interface of High Level Waste Tanks", WSRC-TR-2003-00558, January, 2004. 
WSRC-STI-2007-00552

\section{Appendix}

Table 5. Description of Non-Polarized U-Bends After 100 Days in Test

\begin{tabular}{|c|c|c|c|c|}
\hline $\begin{array}{l}\text { Inhibitor } \\
\text { Level }\end{array}$ & $\begin{array}{l}\text { Nitrate } \\
(\mathrm{M})\end{array}$ & $\begin{array}{c}\text { Heat } \\
\text { Treatment }\end{array}$ & $\begin{array}{c}\text { U-Bend } \\
\text { Appearance }\end{array}$ & Details \\
\hline \multirow[t]{2}{*}{ Low } & \multirow[t]{2}{*}{5.5} & \multirow[t]{2}{*}{ No } & Good & $\begin{array}{l}\text { LAI: Some orange corrosion products at } \\
\text { interface. Deposits alongside weld. }\end{array}$ \\
\hline & & & Good & $\begin{array}{l}\text { VS: Little corrosion on edges. Deposits on and } \\
\text { alongside weld. }\end{array}$ \\
\hline \multirow[t]{2}{*}{ Low } & \multirow[t]{2}{*}{5.5} & \multirow[t]{2}{*}{ Yes } & Good & $\begin{array}{l}\text { LAI: Orange line at interface. Few deposits } \\
\text { above and below interface. }\end{array}$ \\
\hline & & & $\begin{array}{l}\text { Very } \\
\text { Good }\end{array}$ & $\begin{array}{l}\text { VS: Dried brown stalactite on apex. White dusty } \\
\text { crystals covering surfaces. }\end{array}$ \\
\hline \multirow[t]{2}{*}{ Low } & \multirow[t]{2}{*}{8.5} & \multirow[t]{2}{*}{ No } & $\begin{array}{l}\text { Very } \\
\text { Good }\end{array}$ & $\begin{array}{l}\text { LAI: Nothing on surface below line, deposits } \\
\text { above line. White crystalline ear projecting at } \\
\text { line. Orange products on edges. }\end{array}$ \\
\hline & & & Good & $\begin{array}{l}\text { VS: Even coating of dried deposits and/or red- } \\
\text { brown corrosion products. }\end{array}$ \\
\hline \multirow[t]{2}{*}{ Low } & \multirow[t]{2}{*}{8.5} & \multirow[t]{2}{*}{ Yes } & Good & $\begin{array}{l}\text { LAI: Some orange corrosion product at } \\
\text { interface. Deposits above and on weld below } \\
\text { interface. White crystalline ear projecting at line. }\end{array}$ \\
\hline & & & Good & $\begin{array}{l}\text { VS: Even coating of dried deposits and/or red- } \\
\text { brown corrosion products }\end{array}$ \\
\hline \multirow[t]{2}{*}{ Low } & \multirow[t]{2}{*}{8.5} & \multirow[t]{2}{*}{ No* } & Good & $\begin{array}{l}\text { LAI: Little deposits below interface. Small } \\
\text { amount brown deposits above. None at line. Salt } \\
\text { crystals at line. }\end{array}$ \\
\hline & & & Good & $\begin{array}{l}\text { VS: Even coating of brown, coating thicker at } \\
\text { edges and on weld. Stalactite on apex. }\end{array}$ \\
\hline \multirow[t]{2}{*}{ Low } & \multirow[t]{2}{*}{8.5} & \multirow[t]{2}{*}{ Yes* } & Good & $\begin{array}{l}\text { LAI: Broken orange line at interface. Some } \\
\text { deposits/spots of corrosion above and below } \\
\text { interface. }\end{array}$ \\
\hline & & & Good & $\begin{array}{l}\text { VS: Red-brown stalactite on apex. } \\
\text { Deposits on and alongside weld. }\end{array}$ \\
\hline \multirow[t]{2}{*}{ Medium } & \multirow[t]{2}{*}{8.5} & \multirow[t]{2}{*}{ No } & Good & $\begin{array}{l}\text { LAI: Orange corrosion only on edge at interface } \\
\text { line. Nothing below line, some deposits above } \\
\text { line alongside and on weld, especially. }\end{array}$ \\
\hline & & & Okay & $\begin{array}{l}\text { VS: Thick deposits or corrosion products, } \\
\text { especially on, alongside weld. }\end{array}$ \\
\hline \multirow[t]{2}{*}{ Medium } & \multirow[t]{2}{*}{8.5} & \multirow[t]{2}{*}{ Yes } & Good & $\begin{array}{l}\text { LAI: No deposits below interface, and even } \\
\text { coating at and above interface, with some orange. }\end{array}$ \\
\hline & & & Good & VS: Brown-red deposits on apex. \\
\hline
\end{tabular}

*These U-bends did not have surface indentations made through the oxidized layers to reveal fresh metal. They were used to determine the effects of indenting. 